\title{
An Initiative to Address the Gender Imbalance in Tertiary IT Studies
}

\author{
Annemieke Craig, School of Information Systems \\ Jo Coldwell, School of Information Technology \\ Deakin University, Melbourne, Victoria, Australia
}

\author{
acraig@deakin.edu.au; jo.coldwell@deakin.edu.au
}

\begin{abstract}
Gender imbalance in the IT sector is a problem with few females choosing information technology (IT) as a career. This paper describes an initiative conducted in Victoria, Australia, that aimed to expand the career horizons of secondary school girls aged 14 to 18 by showing them the range of career opportunities available in information technology. The event was a two day showcase where industry speakers from a wide variety of areas within the sector spoke about their careers. The event participants - students and their accompanying teachers - were surveyed. Both students and teachers indicated that the Showcase had been a worthwhile event that had made them much more aware of some of the career options available in the IT sector. The most significant finding was that after the event a considerable percentage of the students indicated that they would consider a career in IT, when only about half of those surveyed indicated that they had considered IT beforehand.
\end{abstract}

Keywords: Gender, female, computing, under-representation, recruitment

\section{Introduction}

Australian statistics indicate that the levels of participation in IT education and workforce by women have been low since the 1980s (DEST, 2002). Currently female students represent less than $19 \%$ of all students enrolled in undergraduate Information Technology courses Australia wide (DEST, 2008). This lack of women studying and working in computing is an issue that has been long recognised by academics, the industry, and governments in many western countries including Australia (see for example Adam, Howcroft, \& Richardson 2004; Clarke, 1990; Edwards \& Kay, 2001; Galpin, 2002; Kay, Lublin, Poiner, \& Prosser 1989). To attract girls to computing and retain women once in the field requires 'formal' programmes specifically to address the factors discouraging women's participation (Wasburn \& Miller, 2006). The literature argues that different strategies are required to engage different groups of students. Consequently numer-

Material published as part of this publication, either on-line or in print, is copyrighted by the Informing Science Institute. Permission to make digital or paper copy of part or all of these works for personal or classroom use is granted without fee provided that the copies are not made or distributed for profit or commercial advantage AND that copies 1) bear this notice in full and 2) give the full citation on the first page. It is permissible to abstract these works so long as credit is given. To copy in all other cases or to republish or to post on a server or to redistribute to lists requires specific permission and payment of a fee. Contact Publisher@,InformingScience.org to request redistribution permission. ous intervention programmes specifically aimed at encouraging young females have been designed and implemented (see for example Clayton \& Lynch 2002; Craig, Fisher, Scollary, \& Singh 1998; Goral, 2006; Tsagala \& Kordaki 2007).

\section{The Career Showcase}

The Go Girl, Go for IT 2008 Career Showcase was held in late October at Deakin University in Australia. The 
event was held over two days to enable as many girls to participate as possible with each participant attending on one of the two days only. The target audience for Go Girl, Go for IT were secondary school girls, aged from 14 to 17 from both metropolitan and regional schools in Victoria. Most students attended the event in organised school groups of 2 to 110 students accompanied by teachers. The event aimed to better inform, educate, and inspire these female students on the wide range of careers and options available within the IT industry. By ensuring participants were better informed regarding the variety of careers within the industry, it was anticipated that some of the girls would consider pursuing IT studies beyond secondary school that would enable them to gain qualifications and a career in the IT industry.

This was the third time that this event had been held in Victoria. The first Go Girl, Go for IT Showcase was conducted in October 2001 at Monash University with the second at Deakin University in 2006. Funding to stage the 2008 event was provided through the generous sponsorship of industry organisations, academic institutions, and government departments with planning and implementation of the event staffed by (mostly women) volunteers. The event was therefore able to be free of charge to participants.

There were 28 speakers presenting over the two days of the event, with a number of the presentations repeated in multiple streams. Each stream comprised nine presentations conducted by individuals working in IT or IT related fields. Speakers came from all sectors of the IT industry, including software development, robotics, digital content production, animation, and content management. The intent was to inspire and encourage the girls to consider a wide range of careers offered by this rapidly evolving industry. These presenters provided positive role models for the students, sharing unique real-world experiences and valuable career advice.

During the morning and lunchtime breaks the students were able to attend a Trade Show which aimed to further promote the variety of roles and services in the industry. At lunchtime entertainment was also provided by a popular music band.

\section{Data Collection and Analysis}

A survey method using paper questionnaires was chosen to collect information about the participants' immediate responses to the Go Girl, Go For IT 2008 Career Showcase.

\section{Survey Questionnaires}

The students were issued a student evaluation questionnaire while the teachers were issued a teacher evaluation questionnaire. A total of 1070 usable student questionnaires were returned, giving an overall response rate of $84 \%$. The response rate on the teacher questionnaires was $66 \%$ with 67 usable surveys returned. For reasons of space the Student Survey only is provided in the Appendix.

Each of the questionnaires contained a mixture of closed and open-style questions. Each questionnaire requested participants to name the presentation stream they had attended, enabling analysis of responses based on the streams.

The student questionnaire contained questions designed to collect demographic data including school attended, year level, usage of computers, and whether the students were studying IT at school. The students were asked to identify the presentation sessions they had preferred and what they had learnt from these sessions. There were questions to gauge the students' interests in and perceptions of IT as a career, and whether these were influenced by the Showcase.

The teacher questionnaire contained questions to determine the teachers' interest in IT and establish what discipline area they teach. There were questions about the pre-event communication and how the students were selected to attend. The teachers were asked to rate the organisation and 
management of the Showcase, the facilities provided, and the quality and content of the presentations.

Lastly the students and teachers were asked to rate their overall impressions of the Showcase and make recommendations for future events of this nature.

\section{Data Collection Method and Analysis}

The survey questionnaires were distributed to the students and the teachers at the end of the afternoon session on each day of the event, and the completed questionnaires were collected as the participants left the auditorium. In return for completing the questionnaires, the participants were given a show bag which contained numerous small gifts from sponsors and the book 'Tech girls are chic!'

The survey responses of students and teachers were analysed to provide descriptive information. A variety of statistical tests were performed on this data. Descriptive and statistical analysis of the quantitative data was performed using SPSS. As the data was categorical or ordinal in nature, non-parametric analysis techniques were used. These included Chi-squared tests, Kruskal-Wallis tests and McNemar's change tests. For all statistical tests conducted, a level of $p<0.05$ was used to determine statistical significance.

\section{Results}

\section{Attendance and School Resources}

The teachers who responded to the survey reported that the decision for the girls to attend the Showcase was made at their school by an IT teacher $(67 \%)$, a careers teacher $(15 \%)$, or by others $(17 \%)$. Almost half of the teachers $(48 \%)$ stated that students at their school applied individually to attend the event. More than a quarter of the teachers (28\%) suggested their school attended the

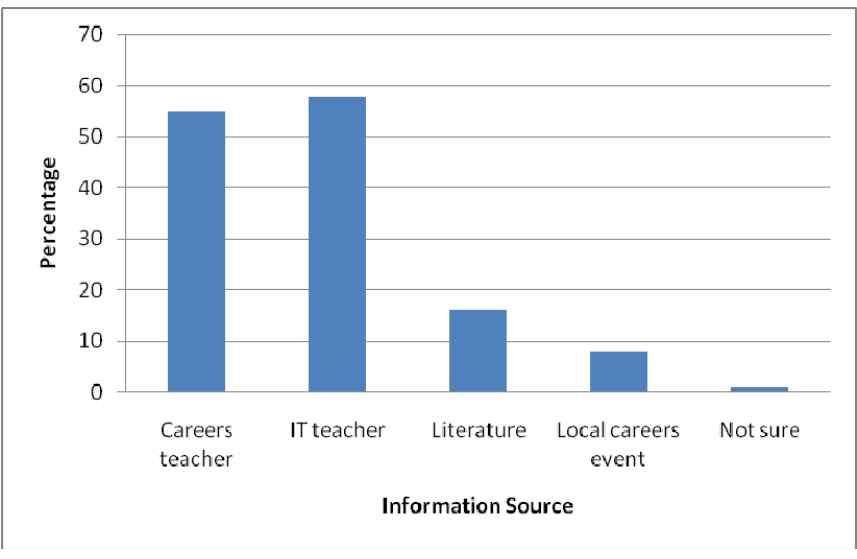

Figure 1: IT resources available at schools event as a compulsory excursion. In most other cases, staff selected the students to attend.

The teachers were also asked to indicate what resources were available at their school for students to gain further information about IT. The most common resources were the Careers and IT teachers. At a number of schools information was available from more than one source hence some teachers gave multiple responses to this question (Figure $1)$.

\section{The Student Computer Experience}

Of the students who responded to the survey, more than half were currently studying or had studied IT at school (64\%). When asked to rate their interest in their IT subject, most indicated some interest, with $33 \%$ claiming that they were very or extremely interested in their IT subject. 
The most common reasons students gave for not studying IT was because they preferred other subjects $(40.3 \%)$ or IT subjects were not offered at their school (18.8\%). Other reasons which comprised $15.4 \%$ of the responses included "could not get in", "don't have time" and "clashes with other subjects".

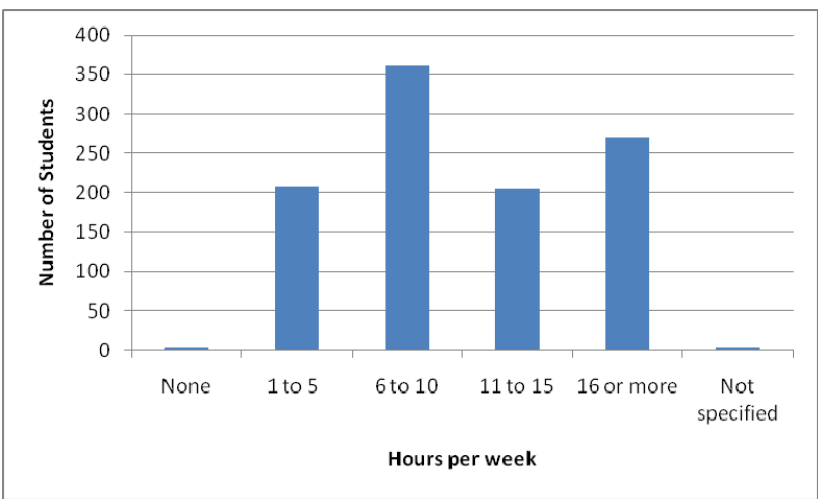

Figure 2: Time spent using a computer by students
Almost all the students who responded to the survey claimed that they used a computer each week. The time spent using computers varied but there were no significant differences according to the Chi Square ${ }^{1}$ result. Estimated weekly computer usage of respondents is shown in Figure 2.

The girls were asked for what purposes they used the computer. The most common usages were for communication $(86 \%)$ and for school work $(88 \%)$. Slightly more than half of the students used computers for games

(57\%) with far fewer spending time on the more technical activity of programming $(7 \%)$. In response to the option for specifying other uses of computers, $19 \%$ of the students responded that they used the computer for 'Other' things like using YouTube, downloading or watching music/movies and viewing photos. Note that students were able to give multiple responses to this question.

\section{Students' View of the Presentations}

Most of the girls (88\%) suggested that they found it helpful having presenters speak about their experiences in IT. The students were asked to nominate one thing that they had learnt from the presentations that they had attended. Their comments have been grouped into five themes and are presented in the order of most to least frequently occurring theme.

1. IT skills and technology

Girls were particularly impressed by the extent of IT use in today's society. They were not only interested in the technology but what went on behind the scenes. Indicative comments representative of what students claimed they learnt follow:

- Art and IT can be combined into one which is amazing

- We can send mails to Mars, but it will take for ages :) around 1 hour

- Google designer- math's not important.

2. IT can be a rewarding and fulfilling career

Compared to the 2006 feedback for this question, many more comments were made from 2008 participants regarding the positive aspects of having a career in IT. Many students learnt that a career in IT can not only bring in some lucrative rewards, but also other personal fulfilling ones.

- you make a hell of a lot of money in IT for doing something you enjoy

- you can travel to great places

- IT can be fun and creative.

${ }^{1}$ The Chi square test result was $\left(\mathrm{x}^{2}(4, \mathrm{~N}=)=7.162, p>0.05\right)$ 
3. Variety and opportunities in IT careers

Many comments also reflected the high level of information students obtained with regards to the variety of work available and the opportunities that a career in IT provides. Specific comments include:

- so many different types of jobs in IT

- IT has a wide variety and range of jobs and experiences

- IT comes in a wide range of careers not just a selected few i.e. IT can be in music, programming etc.

4. Different pathways to a career in IT

Other overwhelming comments were made with regards to the different ways in which one can pursue a career in IT.

- IT has soooo many different categories and different paths you can go down

- IT is a very good as a career. It has lot of options in it

- You don't have to know coding and everything about computers to get a job in IT.

5. IT is not just for males and geeks

A common perception about IT is that it is a male dominated field and most people working in the field are stereotyped as 'geeks'. The event helped ameliorate some of these negative perceptions about IT:

- $\quad$ more to IT itself e.g. its more than a person sitting in front of a computer

- IT is fun, and not only for geeks

- Girls can do just as good even better in IT than guys.

The following quote sums up the general view of what students learnt during the event: Two things I learnt from the sessions were - many false stereotypes surrounding IT and IT has a wide range of all types of opportunities available.

\section{Students' View of a Job in IT}

The students were asked to identify anything they thought they might like about an IT job. Five themes emerged from their responses. These themes were similar to those which had emerged from the 2006 data set though one 2006 theme 'Be at the leading edge with technology' was not as prevalent in 2008 .

Note that many students made comments incorporating several of these themes and therefore they are not mutually exclusive - as evident in the comments displayed.

1. Money and travel

- All the opportunities to work in different places

- Being able to have flexible hours and travelling interstate and overseas

- Freedom to be creative and have fun. Travelling. Money.

2. Variety in the job

- Flexibility, freedom and a positive way to express your creative/professional persona and gain global recognition whilst earning a great income

- I would probably like the variety and choices - with so many areas to succeed in it's great that there is lot's of stuff you can do

- $\quad$ The flexibility and variety of areas.

3. Being creative, researching and developing new skills

- Anything to do with designing, like picture manipulating or websites or things like that also gaming 
- Being creative and coming up with new ideas to improve technology is something I would like

- Designing logos and stuff, making a website or your own blog and research things to make them even better. (as well as security).

4. Achieving global change through the use of IT

- Being able to use IT to help less fortunate. Being able to be creative, providing technology for the future

- How creative you can be and how you can be inventing something completely new. You also have the opportunity to better something that already exists

- I think I would like the fact that you are always exploring and that you get to invent new things and further technology.

5. Interaction with people

- ... I think I would like working in teams and collaborating with other people as well as being creative with websites and the fact that its always changing

- It's interactive with other people

- I think I would like the fact that I wouldn't have to work entirely by myself, that I could work with other people too.

Students were also asked what aspects of a job in IT they would not like. Six themes emerged. Again many comments made by students covered more than one theme.

1. Long hours, stress

- Long hours in front of technology because it would start to give me a headache.

- Long hours ... dealing with complicated machinery

- Too much thinking could be very frustrating and can stress you out

- Staying up late to finish work.

2. Uninteresting, boring work

- Working with computers all the time would be a bit boring

- A hard job, if it was boring, or a competitive workplace. I would not like it if it was very technical

- Working with computers and designing stuff becomes boring.

3. Impediments to health

- I'm not very interested because it will be bad for my eyes and I will live a sedentary lifestyle

- It's unhealthy, you would be deficient in vitamin D and could become fat. You get headaches

- I don't know! I might damage my eyes.

4. Dealing with technical issues

- Solving technical problems.

- technical difficulties, wires and plugs!

- technology being unreliable all the codes mumbo jumbo.

5. Stigma associated with working in IT

- Being called a geek

- Being stereotyped as a robot and sitting inside

- people thinking that your a nerd/geek when your not.

6. Having to learn new skills

- Having to keep up with all the new technologies 
- having to think to create something new and original

- learning about codes and languages of computers which is needed to make designs, et.c

\section{Students' Interest in an IT career}

A series of questions were asked to attempt to gauge students' interest in IT and pursuing IT as a career. The results indicated that:

- For the majority of the girls (86\%) the event had given them a positive feeling about IT

- More than a third of the students (39\%) claimed that they would investigate more about IT (likely or very likely)

- More than a third of the girls (38\%) also claimed that they would consider selecting ITbased subjects at school in the following year.

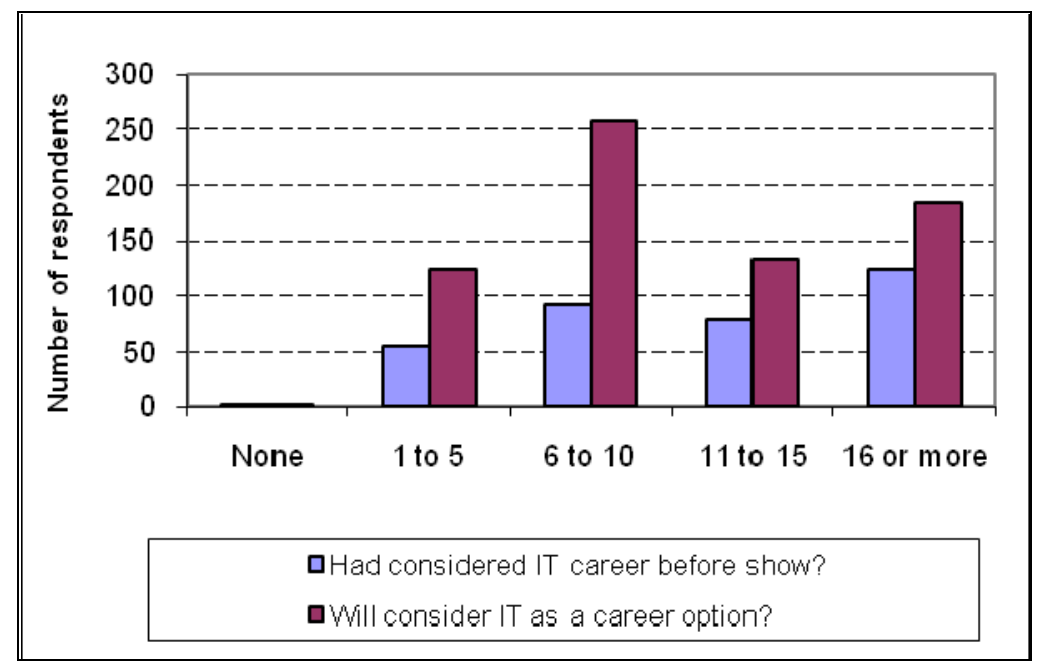

Figure 3: Students' pre and post Showcase interest in an IT career according to HOURS of usage

Disregarding nil responses, $35 \%$ of the students reported that they had considered IT as a career before the Showcase. However, after the event over two-thirds (71\%) of the students stated that they would consider a career in IT. This change was tested using a McNemar's test ${ }^{2}$ and found to be significant, indicating that participation in the event did influence the students' interest in IT. The change in this rating was tested for students grouped according to computer usage (Figure 3). In every case the McNemar's test showed the change was significant with the exception that those who did not use a computer had no significant change in their consideration of IT as a career. However it should be noted that this only applied to four participants. With the exception of this group, the results indicate that this change was consistent across all demographic groups.

The responses to these interest questions were also compared according to whether IT was studied at school. For each interest question, the students that had studied IT at school had more interest in IT than those that had not studied IT (see Table 1). In fact they were almost twice as likely to have considered a career in IT before the Showcase compared to those who did not study IT.

\footnotetext{
2 McNemar's test is a statistical method used to measure the changes in responses for two related dichotomous variables. This test gave a result of $\mathrm{N}=966$, exact $\mathrm{p}=0.000(p<0.05)$
} 
Initiative to Address the Gender Imbalance

There appeared to be little difference in the school type (private, public, independent, religious etc) a student attended with regards their interest in IT.

Table 1: Students' interest in IT according to whether they are STUDYING IT or not

\begin{tabular}{|l|c|c|c|}
\hline \multicolumn{3}{|l|}{$\%$ of 'Yes' responses for session } & \\
\cline { 1 - 1 } Interest question & Studies IT & Not studied IT & $\begin{array}{l}\text { Chi } \\
\text { Square }\end{array}$ \\
\hline $\begin{array}{l}\text { Did you find it helpful having presenters speak } \\
\text { about their experiences in IT? }\end{array}$ & $93.3 \%$ & $89.5 \%$ & $4.5^{*}$ \\
\hline $\begin{array}{l}\text { From today's events did you get a positive } \\
\text { feeling about careers in IT? }\end{array}$ & $92.3 \%$ & $85.7 \%$ & $11.3^{*}$ \\
\hline $\begin{array}{l}\text { Would you consider IT as a career option? } \\
\text { Had you considered IT as a career option be- } \\
\text { fore today? }\end{array}$ & $78.3 \%$ & $56.6 \%$ & $51.0^{*}$ \\
\hline
\end{tabular}

* indicates chi-square test significant at $p<0.05$

The responses were also compared with the year level in which students were (Table 2). In most Victorian secondary schools students are placed in Years 7(around 11-12 years of age) through to Year 12 (generally 17-18 years of age).

As another indication of the students' level of interest in IT, after the event the students were asked to rate their interest in IT. Very few students (8\%) indicated no interest in IT after the Showcase.

Table 2: Students' interest in IT according to school YEAR LEVEL

\begin{tabular}{|c|c|c|c|c|c|c|}
\hline \multirow[b]{2}{*}{ Interest question } & \multicolumn{4}{|c|}{$\%$ of 'Yes' responses for session } & \multirow[b]{2}{*}{$Y 12$} & \multirow{2}{*}{$\begin{array}{l}\text { Fishers } \\
\text { Exact }\end{array}$} \\
\hline & $Y 8$ & Y9 & $Y 10$ & $Y 11$ & & \\
\hline $\begin{array}{l}\text { Did you find it helpful having } \\
\text { presenters speak about their } \\
\text { experiences in IT? }\end{array}$ & $83.3 \%$ & $89.7 \%$ & $98.0 \%$ & $96.3 \%$ & $100.0 \%$ & Yes* \\
\hline $\begin{array}{l}\text { From todays events did you get } \\
\text { a positive feeling about careers } \\
\text { in IT? }\end{array}$ & $81.7 \%$ & $86.4 \%$ & $96.9 \%$ & $97.3 \%$ & $75.0 \%$ & Yes* \\
\hline $\begin{array}{l}\text { Would you consider IT as a } \\
\text { career option? }\end{array}$ & $78.4 \%$ & $64.3 \%$ & $75.8 \%$ & $88.2 \%$ & $66.7 \%$ & Yes* \\
\hline $\begin{array}{l}\text { Had you considered IT as a } \\
\text { career option before today? }\end{array}$ & $23.7 \%$ & $27.3 \%$ & $42.0 \%$ & $63.3 \%$ & $66.7 \%$ & Yes* \\
\hline
\end{tabular}

* indicates Fishers Exact test significant at $p<0.05$ (cell counts $<5$ for at least one cell) 


\section{Teachers' View of the Showcase}

The teachers were overwhelmingly positive in their praise of the Showcase, with $88.9 \%$ rating it as great or excellent. As further evidence of their enthusiasm for the event, $85 \%$ claimed that they would consider attending again.

Over half the teachers who responded to the questionnaire (51\%) taught in the IT area. The next largest group was from Careers (13\%) with the remaining teachers from 'Other' areas (22\%) included a wide assortment of discipline areas such as curriculum and media studies. All respondents indicated that they had an interest in IT with $82 \%$ claiming that they were very interested or extremely interested in IT.

The teachers identified a number of benefits from attending the event. When asked specifically: 'Did you learn anything from today's event?' comments were made with regards to:

1. Career information

Many teachers were educated on the diversity and varied career pathways for students

- Careers pathways

- $\quad$ The breadth of employment opportunities, flexibility in working hours (for self employed)

- Yes, many interesting careers in IT and new knowledge.

2. Knowledge about IT technology and ideas for teaching

- The use of IT for police. The new technologies for phones

- Yes! Lots of examples of uses of IT to refer to in my teaching.

- Yes, many interesting careers in IT and new knowledge. Police talk was great, Kids thoroughly liked that.

3. Motivation to learn more and teach better

- Some interesting websites, how to engage girls further

- Yes! Lots of examples of uses of IT to refer to in my teaching. It was great to have industry context and point of view - direction of IT etc where I feel I do not have the experience to refer to in my teaching

- Yes I want to know more and work with higher levels of students. I need to build on my knowledge and play some more. Increased passion in IT.

The teachers found it helpful for the girls to have role models speak about their experiences in IT. When asked specifically "Do you think it was helpful for the girls having role models speak about their experiences in IT? Please explain." Three themes emerged from their responses. These themes are presented in the order of most to least frequent occurring theme.

1. Demonstrating the diversity of IT jobs

- Definitely - ITs a diverse area not many girls realise this - but now they do which is awesome for the IT industry

- Good to see a wide diversity of people who have been successful in IT.

- Yes, it showed a variety of different presenters in different roles.

2. Providing an insider's view of the IT industry

- Absolutely, all our girls related to at least one of the speakers

- Absolutely helpful!! The speakers provided a valuable insight into their personal journeys - the pathways that have led to their IT careers etc

- Most of the speakers were very engaging and motivating for the girls. A good range between technical and lifestyle effects of working in IT. 
3. Motivating girls to enter an IT career

- Yes - need to motivate girls to choose IT electives and subjects now and in the future

- The girls are talking more about the possibilities of their future

- Yes, there were certainly a number of students who expressed a wish to enter IT and commented on aspects of the presentations that impacted on them.

Although both teachers and students were impressed overall with the Showcase, teachers were much more likely to rate the event as excellent versus the students who were more likely to rate it as $\mathrm{OK}$ or lower.

\section{Recommendations}

The analysis of the data enabled a number of recommendations to be made to the Steering Committee for consideration for future events:

- IT teachers are instrumental in making the decision for school groups to attend. Marketing should be strongly focused on IT teachers (rather than principals or careers teachers) to make sure they are aware of the event.

- The greatest impact appears to have been on students in Years 10 and 11 so these year levels need to be strongly encouraged to attend.

- A criterion by which to evaluate programs such as Go Girl, Go for IT needs to be developed when the program itself is planned. A clear direction on what constitutes a successful program should be discussed from the beginning. Is success that the girls had a good day? Is success that the girls learnt something? Is success that the day ran smoothly? Is success that the day had an impact on the girls? What impact is desired: i.e., That the girls consider undertaking an IT subject? That the girls undertake an IT subject in the following year? Or that they investigate IT further as a possible career?

\section{Limitations and Further Work}

While there was an excellent response rate ( $84 \%$ ) the survey respondents may be those who were already interested in IT and already positive about a career for the IT sector.

Girls of that age are often unsure about their career choice. Gender in computing research indicates that girls are more likely than boys to be influenced by parents or a close personal contact in their career choices (Margolis \& Fisher, 2002).

The big question is where these students will go once they have finished their secondary schooling. The girls who attended Showcase 2006 are being surveyed at present. This will be the first longitudinal survey since the events was held. While the short term impacts of such an event are clearly positive there is no clear idea yet about the longer term impact and whether or not the students will follow through or even think about IT as a career choice.

\section{Conclusions}

Based on the immediate feedback, the Showcase was a huge success in the eyes of both students and teachers. There is general agreement that the format of the Showcase works well.

Currently the Showcase is held every two years which means that contact is lost with schools for a period of time only to be established again. One way of maintaining a link between the Showcase and schools is to provide information on an ongoing basis. This could be achieved through the development of a website with information and activities that could maintain and build on the 
girls' interest and be used as a means of keeping the IT and Careers teachers focused on the Showcase too.

Overall the Showcase appears to have a positive impact on students' perceptions of IT, which is overall the main objective of the event. Whether this impact has any long term benefits has still to be evaluated. A follow-up exercise is being undertaken of the 2006 cohort now with a further follow up of the 2008 attendees planned for 2011.

\section{Acknowledgments}

To the many volunteers, including members of VicWic, WIT (Vic) and the Victorian ICT Network for Women without whose energy and passion these events could not happen - our sincere thanks. Also our thanks to Wendy Maton for help with analysis of the data.

\section{References}

Adam, A., Howcroft, D., \& Richardson, H. (2004). A decade of neglect: Reflecting on gender and IS. New Technology, Work and Employment, pp. 222 - 239.

Clarke, V. (1990). Sex differences in computing participation: Concerns, extent, reasons and strategies. Australian Journal of Education, 34(1), 52 - 66.

Clayton, D., \& Lynch, T. (2002). Ten years of strategies to increase participation of women in computing programs - The Central Queensland University experience: 1999-2001. Inroads SIGCSE Bulletin, 34(2), 89 - 93.

Craig, A., Fisher, J., Scollary, A., \& Singh, M. (1998). Closing the gap: Women education and information technology courses in Australia. Journal of Systems Software, 40(1), 7 - 15.

DEST: Department Of Education Science and Training. (2002). Australian selected higher education statistics, Table 2 All students with user specified field of study by gender, 1989 to 2000 .

DEST: Department Of Education, Science and Training. (2008). Selected higher education statistics. Retrieved August 22, 2008, from http://www.dest.gov.au/sectors/higher_education/publications resources/statistics/publications higher education statistics collections.htm\#studpubs

Edwards, J., \& Kay, J. (2001). A sorry tale-a study of women's participation in IT higher education in Australia. Journal of Research and Practice in Information Technology, 33(4), 329 - 335.

Galpin, V. (2002). Women in computing around the world. Inroads SIGCSE Bulletin, 34(2), 94 - 100.

Goral, C. (2006) How to increase women's impact on technology - Changing culture, curriculum and technology. Anita Borg Institute for Women and Technology.

Kay, J., Lublin, J., Poiner, G., \& Prosser, M. (1989). Not even well begun: Women in computing courses. Higher Education, 18(5), 511 - 527.

Margolis, J., \& Fisher, A. (2002). Unlocking the clubhouse: Women in computing. Cambridge, Massachusetts, USA: The MIT Press.

Tsagala, E., \& Kordaki, M. (2007). Critical factors influencing secondary school pupil's decisions to study computing in tertiary education: Gender differences. Educ Inf Technol,12, 281-295.

Wasburn, M., \& Miller, S. (2006). Still a chilly climate for women students in technology: A case study. In M. F. Fox, D. G. Johnson, \& S. V. Rosser (Eds.), Women, gender, and technology. University of Illinois. 


\section{Biographies}

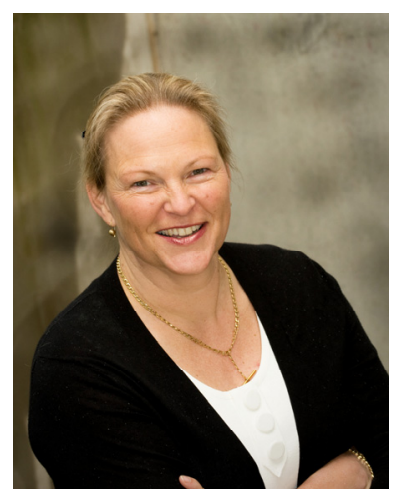

Dr. Annemieke Craig is a Senior Lecturer and Unit Chair in Information Systems in the Faculty of Business and Law. Annemieke is a proponent of computing studies and careers through active involvement in initiatives such as Deakin's successful Go Girls, Go for IT! Event. Her research interests include online learning and the use of technology in teaching in higher education. Annemieke also researches in the fields of access and equity with particular emphasis on trying to improve the profile of women in computing and to encourage more female students to consider computing courses.

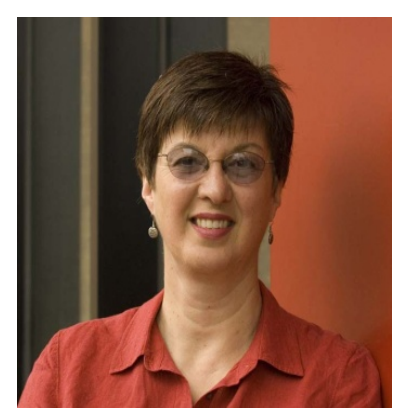

Dr. Jo Coldwell joined Deakin in 1997 where she is currently Associate Head (Teaching and Learning) in the School of Information Technology. Before joining Deakin she gained a wealth of experience in both academia (in Australia) and industry (in both Australia and the UK). Since 2000 she has taught extensively online and her research interests lie in a number of areas associated with engaging tertiary teachers and learners in and with technology. 


\section{Appendix-Student Survey}

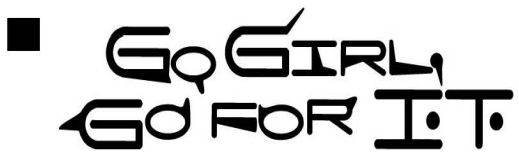

\section{GO GIRL, GO FOR IT 2008 \\ Student Evaluation \\ Deakin University}

For us to understand what you liked and did not like about Go Girls we ask that you please take the time to answer a few questions. At the end of the day hand this sheet to a Go Girl volunteer at the front of the room before leaving. In return you will be given a show bag full of great gifts!!!

Please indicate responses by placing a cross $囚$ in the appropriate box

Q1. Which group are you in? $\square$ Orange $\square$ Silver $\square$ Blue $\square$ Red

Q2. What year are you currently in at school?

$$
\square \text { Year } 8 \quad \square \text { Year } 9 \quad \square \text { Year } 10 \square \text { Year } 11 \quad \square \text { Year } 12
$$

Q3. What school do you attend?

Q4. How many hours do you use a computer per week? (please cross one)

$\square$ None $\square$ 1-5hours $\square$ 6-10 hours $\square 11-15$ hours $\square 16$ or more

Q5. What do you use computers for? (please cross ALL that apply)

$\begin{array}{ll}\square \text { Email } \square \text { Assignments } & \square \text { Chatting/IM/MSN } \\ \square \text { Building Web Sites } & \square \text { Web surfing } \square \text { Gagramming } \\ \square \text { Other, please indicate } & \square \text { Facebook/My Space }\end{array}$

Q6. Are you studying an IT subject at school? $\square$ Yes $\square$ No

If Yes.... please describe the IT subject (cross only one box)

$\square$ Dull boring $\square$ Mildy interesting $\square$ Interesting $\quad \square$ very interesting $\square$ Extremely interesting

If No.... is there any particular reason why you don't study IT?

$\square$ Not offered $\square$ Not interested $\quad \square$ Prefer other subjects $\quad \square$ It will be boring

$\square$ It will be too hard $\quad \square$ other, please indicate

Q7. Of the sessions you attended today which was the best and why?

Q8. What were two things that you learnt from the sessions you attended which you did not know before?

(1)

(2) 
Q9. What do you think you would like about a job in IT?

Q10. What do you think you would NOT like about a job in IT?

Q11. How likely are you to select IT based subjects next year at school?
$\square$ very likely $\square$ Likely
Not sure
Not likely
$\square$ Never

Please explain your reasons:

Q12. How likely are you to further investigate career options in the IT field?

$\square$ Very likely $\square$ Likely $\square$ Not sure $\square$ Not likely $\square$ Never

Please explain your reasons:

13. Did you find it helpful having presenters speak about their experiences in IT?

$\begin{array}{ll}\square \text { Yes } & \square \text { No } \\ \square \text { Yes } & \square \text { No } \\ \square \text { Yes } & \square \text { No } \\ \square \text { Yes } & \square \text { No }\end{array}$

Q14. From today's event did you get a positive feeling about careers in IT?

Q15. Would you consider IT as a career option?

Q16. Had you considered IT as a career option before today?

Q17. What parts of today's event did you attend? (cross all that apply)

$$
\square \text { Trade show } \square \text { Sessions before morning tea } \quad \square \text { Sessions before lunch } \square \text { Sessions after lunch }
$$

Q18. After attending today how interested are you in IT?

$\square$ Extremely interested $\square$ very interested $\square$ Interested $\square$ A little interested $\square$ Not interested

Q19. What was your overall impression of the day?

$$
\square \text { Awesome } \square \text { Great } \square \text { OK } \square \text { Not that good } \square \text { Unsatisfactory }
$$

Q20. Do you have any suggestions to make the event better next time or any other comments? 